\title{
Protein Deimination in the Rat Brain: Generation of Citrulline- Containing Proteins in Cerebrum Perfused with Oxygen-Deprived Media
}

Hiroakj Asaga and Akinito Ishigami

Department of Bioactivity Regulation, Tokyo Metropolitan Institute of Gerontology, 35-2 Sakae-cho, Itabashi-ku, Tokyo 173-0015, Japan

(Received 7 September 2000; and accepted 25 September 2000)

\begin{abstract}
The central nervous system contains the posttranslational modification enzyme, peptidylarginine deiminase (PAD; EC 3.5.3.15) type II. This enzyme catalyzes the deimination of arginine residues of proteins in a calcium ion-dependent manner, thereby, forming citrulline residues. Previously, we found postmortem deimination of glial fibrillary acidic protein in rat spinal cord. In the present study, therefore, we studied the deimination further as a possible cause of neurodegeneration in cerebrum. Additionally, as a model of tissue damage, the effect of oxygen deprivation on protein deimination in rat cerebral tissue was also analyzed by applying systemic perfusion with an emulsion of perfluorochemicals. In the presence of sufficient oxygen, such perfusion caused only negligible formation of citrullinated proteins. However, deprivation of oxygen produced by the perfusion medium resulted in preferential deimination of many kinds of high-molecular-weight $(>55 \mathrm{kDa})$ proteins. Deiminated protein immunoreactivity was found in all regions of the cerebrum but was relatively more intense in the hypothalamus and the lateral amygdaloid nucleus. Most of the deiminated protein-positive cells seemed to be astrocytes. Some neuronal cells in the lateral amygdaloid nucleus became positive after prolonged perfusion with oxygen-deprived medium, although the PAD immunoreactivity appeared only in astrocytes. These results indicate that PAD type II localizes mainly in astrocytes of the cerebrum and that a consequence of hypoxia is enzyme activation that deiminates proteins in astrocytes and some neurons. Such deimination of proteins may be a useful marker of nerve cell degeneration.
\end{abstract}

Peptidylarginine deiminases (PADs) (proteinarginine deiminases, protein-L-arginine iminohydrolases; EC 3.5.3.15)(30, 36, 38, 40) are a group of posttranslational modification enzymes that deiminate protein arginine residues in calcium ion-dependent manner, yielding citrulline residues (Fig. 1). PADs are distinct from nitric oxide synthetases and arginine deiminase, which convert free arginine to citrulline. Of the four types of

Correspondence to: Dr Hiroaki Asaga at the above address.

Tel: +81-3-3964-3241; Fax: +81-3-3579-4776; E-mail: asagahi@tmig.or.jp
PADs known in mammals $(2,3,16,21,36,38)$, only PAD type II is a proven occupant of the central nervous system $(3,18,38,40)$. Immunocytochemical studies have localized PAD type II in glial cells (3), especially astrocytes (5, 39) and microglial cells (39). Since deiminated proteins were rarely detected in the enzymepositive organs examined with our sensitive detection method $(5,32)$, we assumed that PAD type II is normally inactive. However, glial fibrillary acidic protein (GFAP) was highly susceptibile to the attack of PAD type II after excision of the rat spinal cord $(5,32)$, suggesting that this enzyme becomes activated in nerve tissues during patho- 




-Arg- $\quad$-Cit-

Fig. 1 Conversion of arginine residue in proteins to citrulline residue catalyzed by PADs.

logical conditions.

Citrulline is not incorporated into proteins by the ordinary biosynthetic pathway. Consequently, the presence of citrulline residues in proteins can be taken as evidence of deimination catalyzed by PADs. Deimination of arginine residues (citrullination) abolishes their positive charge, resulting in products that differ significantly in structure and function from native proteins $(14,20,35,37$, 41 ). Therefore, protein deimination in pathological aspects is of great intrest.

Here, we used hypoxia to simulate tissue damage and tested its effect on the generation of citrullinated proteins as a consequence of activating cerebral PAD type II. To regulate subtle physiological conditions in the cerebrum in situ, we utilized a systemic perfusion technique with an emulsion of perfluorochemicals that can transport as much oxygen as blood $(27,28)$. As a result, high-molecular-weight deiminated proteins were generated in rat cerebra perfused with oxygen-depried media. Although PAD type II seemed to be confined to astrocytes, which also contained the deiminated proteins, these proteins appeared in some neuronal cells as well.

\section{MATERIALS AND METHODS}

\section{Animals and Perfusion}

The male and female Wistar rats (3-5 months of age) used here were housed in an environmentally controlled room $\left(22 \pm 1^{\circ} \mathrm{C}\right.$; lights on, 8:00-20:00 h) with free access to food and water. The Animal Care and Use Committee of Tokyo Metropolitan Institute of Gerontology approved the experimen- tal protocol used. All operations were performed under pentobarbital anesthesia, and all perfusion experiments were done in triplicate. Transcardial perfusions began within $50 \mathrm{~s}$ after dissection of each rat's diaphragm to avoid transient oxygen deficiency before initiating perfusion. Perfusion followed at $4 \mathrm{~mL} / \mathrm{min}$ within a back pressure range of $40-60 \mathrm{mmHg}$ using perfusion media kept at $37^{\circ} \mathrm{C}$. The temperature of test animals' heads was also kept at $37^{\circ} \mathrm{C}$ by heating with a light bulb. We used Earle's balanced salt solution or Fluosol, a stable emulsion of $20 \%$ perfluorochemicals in a balanced salt solution, for intravascular injections $(27,28)$ (kindly supplied from Green Cross Co., Osaka, Japan) as a perfusion medium. These were equilibrated either with $95 \% \mathrm{O}_{2}$ and $5 \% \mathrm{CO}_{2}$ or $95 \%$ air and $5 \% \mathrm{CO}_{2}$ prior to use. After the application of perfusion medium for a given time, the cerebrum was further perfused with ice-cold phosphate-buffered saline (PBS) for $15 \mathrm{~min}$ without heating of the head to stop the enzyme reaction and wash out perfluorochemicals that might interfere with later analyses. The cerebrum was quickly excised and sagittally cut into halves on ice-cold dishes. One half was immediately frozen with liquid nitrogen and stored at $-70^{\circ} \mathrm{C}$ until use for protein analysis, the other half was fixed for histological and immunocytochemical examinations.

\section{Tissue and Homogenate Incubation}

Cerebral tissues without perfusion were quickly excised. Some of them were incubated on ice or at room temperature $\left(22^{\circ} \mathrm{C}\right)$ for $30 \mathrm{~min}$ in covered Petri dishes. They were then frozen and stored for protein analysis. Other tissues were homogenized with about 9 vol. of $0.1 \mathrm{M}$ Tris- $\mathrm{HCl}, \mathrm{pH} 7.4$, containing $1 \mathrm{mM}$ phenylmethanesulfonyl fluoride (PMSF), $1 \mu \mathrm{M}$ pepstatin and $1 \mu \mathrm{M} \mathrm{CaCl}$. This homogenate was incubated on ice or at room temperature for $30 \mathrm{~min}$. At the end of incubation, the homogenate was cooled with ice-cold water, and sodium dodecyl sulfate (SDS) and EDTA were added to final concentrations of $4 \%(\mathrm{w} / \mathrm{v})$ and $2 \mathrm{mM}$, respectively. The homogenate was also subjected to biochemical analysis.

\section{Biochemical Analysis of Deiminated Proteins}

The frozen cerebral tissues were pulverized in a mortar while cooled with dry ice. The resulting powder was dissolved in $4 \%(\mathrm{w} / \mathrm{v})$ SDS contain- 
ing 0.1 M Tris-HCl, pH 7.4, $2 \mathrm{mM}$ EDTA, and 1 $\mathrm{mM}$ PMSF by sonication and heating in boiling water for $4 \mathrm{~min}$. The protein concentration was determined by the method of Lowry et al. (21) using bovine serum albumin as a standard. All samples were then adjusted to $5 \%(\mathrm{v} / \mathrm{v})$ in 2 mercaptoethanol and $5 \mu \mathrm{g} / \mu \mathrm{L}$ in proteins. Proteins were resolved by SDS-polyacrylamide gel electrophoresis (SDS-PAGE)(19). The amount of proteins applied was $50 \mu \mathrm{g} /$ lane. The resolved proteins were blotted on a nitrocellulose membrane (BA-S85)(Schleicher and Schuell, Dassel, Germany). For detection of deiminated proteins, citrulline residues on the blot were chemically modified by overnight incubation at $37^{\circ} \mathrm{C}$ in $0.0125 \% \mathrm{FeCl}_{3}, 2.3 \mathrm{M} \mathrm{H}_{2} \mathrm{SO}_{4} 1.5 \mathrm{M} \mathrm{H}_{3} \mathrm{PO}_{4}, 0.25 \%$ diacetyl monoxime, $0.125 \%$ antipyrine, and 0.25 $M$ acetic acid (modification medium)(32). The blot was then incubated with anti-modified citrulline $\operatorname{IgG}(0.125 \mu \mathrm{g} / \mathrm{mL})(32)$. The bound antibodies were detected using horseradish peroxidase-conjugated goat anti-rabbit IgG (BioRad Laboratories, CA) and ECL Western blotting detection reagents (Amersham International plc, Buckinghamshire, England). Total proteins were visualized by Amido Black $10 \mathrm{~B}$ staining.

\section{Immunocytochemical Detection of Deiminated Proteins}

One-half of each cerebrum was immersed in icecold PBS containing 4\% (w/v) paraformaldehyde and kept at $4^{\circ} \mathrm{C}$ for one day. The tissue was then equilibrated with PBS containing $30 \%(\mathrm{w} / \mathrm{v})$ sucrose and embedded in O. C. T. compound 4583 (Miles Inc., IN) before cutting into $4 \mu \mathrm{m}$ thick cryosections. Sections were mounted on gelatin-coated glass slides and dried under a stream of air. Deiminated proteins were detected as described (5). Briefly, sections were post-fixed with $2.5 \%$ glutaralaldehyde in PBS, and then they were incubated in the modification medium at $37^{\circ} \mathrm{C}$ for $3 \mathrm{~h}$ to modify citrulline residues in situ. Control sections were incubated in the medium free from diacetyl monoxime, antipyrine, and acetic acid. Indirect immunostaining of deiminated proteins was performed with anti-modified citrulline $\operatorname{IgG}(0.25 \mu \mathrm{g} / \mathrm{mL})$ and the Vectastain Elite $\mathrm{ABC}$ kit (Vector Laboratories, Inc., CA) using 3,3'-diaminobenzidine as a chromogenic substrate. Some sections were also subjected to hematoxylin and eosin staining for histological examinations.
Immunocytochemical Detection of PAD type II and Markers

PAD type II and cell markers were stained by the indirect fluorescence method using rabbit antiPAD type II antiserum (40), rabbit anti-GFAP antiserum (Medac Gesellschaft fur Klinische Spezialpraparate mbh, Germany), monoclonal antibody to microtubule-associated protein 2 (MAP2)(MAB364, Chemicon International Inc., CA), and biotin-labeled B4 isolectin of Bandeiraea simplicifolia-1 (Vector Laboratories)(34). For double immunostaining of PAD type II and GFAP, sections were first stained with anti-PAD type II using the Vectastain Elite $\mathrm{ABC}$ kit and the 3-Amino-9-ethylcarbazole (AEC) substrate kit (Vector Laboratories). The sections were washed with $0.1 \mathrm{M}$ glycine- $\mathrm{HCl}$ buffer $(\mathrm{pH} 2.2)$ for 15 min and 3 times with PBS. Finally, the sections were incubated with anti-GFAP and stained by using the Vectastain ABC-Alkaline phosphatase kit and Alkaline phosphatase substrate (III) kit (Vector Laboratories).

\section{RESULTS}

\section{Western Blot Analysis of Deiminated Proteins}

In Fig. 2, the immunoblotting profiles of deiminated proteins in cerebral homogenates are compared with typical profiles of total proteins and immunoreactive GFAP. When the cerebral tissue was excised and examined immediately after sacrifice of test rats, no significant signals were seen in the protein extracts (Fig. 2B, lane 1). However, after incubation of the cerebral tissue at room temperature for $30 \mathrm{~min}$, a major signal appeared (about $50 \mathrm{kDa}$; Fig. 2B, lane 2). This band comigrated with immunoreactive GFAP (Fig. 2C) in agreement with our previous finding in incubated spinal cord (5). No significant signals were observed in tissues left on ice for $30 \mathrm{~min}$ (data not shown) or in homogenates not incubated (Fig. 2B, lane 3). However, a citrullinated protein band with trailing faint smears was visible after incubation of the homogenate with 1 $\mu \mathrm{M}$ of exogenous $\mathrm{Ca}^{2+}$ (Fig. 2B, lane 4). This band also comigrated with immunoreactive GFAP. No such deiminated protein band was observed in homogenate cultured in $2 \mathrm{mM}$ EDTA (data not shown).

To study protein deimination in a brain lesion, we used a transcardial perfusion to simulate that physiological condition. Prompt perfusion with 


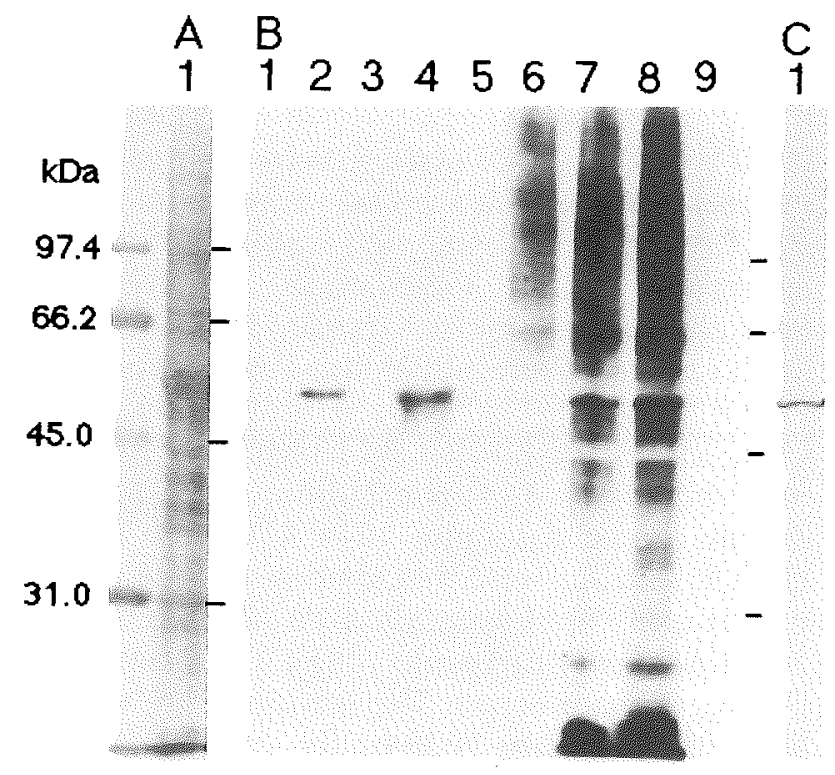

Fig. 2 Electrophoretic profiles of deiminated proteins formed in the cerebrum under various conditions. These protein samples were processed for Western blot analyses as described in the text. A, typical protein profile detected by Amido black staining; $B$, deiminated protein profiles; $C$, immunoreactive GFAP profiles. Lane 1, fresh tissue quickly excised without perfusion; lane 2, after incubation of the tissue for $30 \mathrm{~min}$ at room temperature; lane 3, cerebral homogenate without incubation; lane 4, after incubation of cerebral homogenate in the presence of $1 \mu \mathrm{M}$ of exogeneous calcium ion; lane 5 cerebral tissue perfused for $30 \mathrm{~min}$ with fully oxygenated Fluosol; lane 6, cerebral tissue perfused for $30 \mathrm{~min}$ with oxygen-deprived Fluosol; lane 7 , perfused for $60 \mathrm{~min}$ with oxygen-deprived Fluosol; lane 8, perfused for $100 \mathrm{~min}$ with oxygen-deprived Fluosol; lane 9, perfused for $100 \mathrm{~min}$ with fully oxygenated Fluosol.

ice-cold PBS after dissection of the diaphragm did not cause detectable protein deimination (data not shown), indicating the quenching of postmortem deimination reactions by rapid cooling of tissues with ice-cold PBS. By chance, we found deiminated, high-molecular-weight $(>55$ $\mathrm{kDa}$ ) proteins when perfusion was delayed after dissection of the diaphragm (data not shown). Similarly, prompt perfusion with oxygenated Earle's balanced salt solution resulted in deimination within $15 \mathrm{~min}$ (data not shown). Since an oxygen deficiency evidently caused protein citrullination in the cerebrum, we then designed a perfusion protocol using Fluosol, which can transport as much oxygen as blood $(27,28)$. As expected, perfusion with Fluosol equilibrated with $95 \% \quad \mathrm{O}_{2}$ and $5 \% \quad \mathrm{CO}_{2}$ (fully oxygenated Fluosol) did not produce measurable protein deimination (Fig. 2B, lane 5). In contrast, perfusion with Fluosol equilibrated with $95 \%$ air and $5 \% \mathrm{CO}_{2}$ (oxygen-deprived Fluosol) caused obvious protein deimination (Fig. 2B, lane 6). The deiminated protein bands were broad smears, indicating a relatively large molecular mass $(>55$ $\mathrm{kDa}$ ). The profile was similar to those obtained after delayed perfusion with ice-cold PBS and perfusion with balanced salt solution. Lanes 7 and 8 in Figure 2B show the results of prolonged perfusion with Fluosol. Control perfusion with fully oxygenated Fluosol caused little protein deimination, even after $100 \mathrm{~min}$ (Fig. 2B, lane 9). Prolonged perfusion with oxygen-deprived Fluosol resulted in increasing protein deimination (Fig. 2B, lanes 6-8). Low-molecular-weight deiminated proteins were also detectable at 60 or 100 min of perfusion time (Fig. 2B, lanes 7 and 8). A major protein component at about $55 \mathrm{kDa}$ was not deiminated during this prolonged perfusion, indicating that this reaction was not nonspecific. No appreciable differences were observed among total protein profiles of all samples examined.

\section{Macroscopic Localization of PAD Type II and Deiminated Proteins}

Sections stained with hematoxylin and eosin were compared with those reacted with anti-PAD type II and also with other probes to various markers of cerebral cells. According to macroscopic examination, PAD type II immunoreactivity was significantly enriched in the dentate gyrus of hippocampus, the stratum radiatum moleculare, and the hypothalamus (Fig. 3A). Enrichment was also appreciable in the retrosplenial granular cortex, the parietal cortex, and the anterior cortical amygdaloid nucleus. Perfusion with oxygendeprived Fluosol did not significantly change the immunohistochemical localization of the enzyme (data not shown). No difference in MAP2 immunoreactivity was observed between sections perfused with oxygenated versus oxygen-deprived Fluosol (Fig. 3B). No deiminated proteins were detected in the section obtained after perfusion with fully oxygenated Fluosol (Fig. 3C). Deiminated proteins generated during perfusion with oxygen-deprived Fluosol were focused conspicuously in the lateral and basolateral amygdaloid nucleus and the hypothalamus (Fig. 3D). 


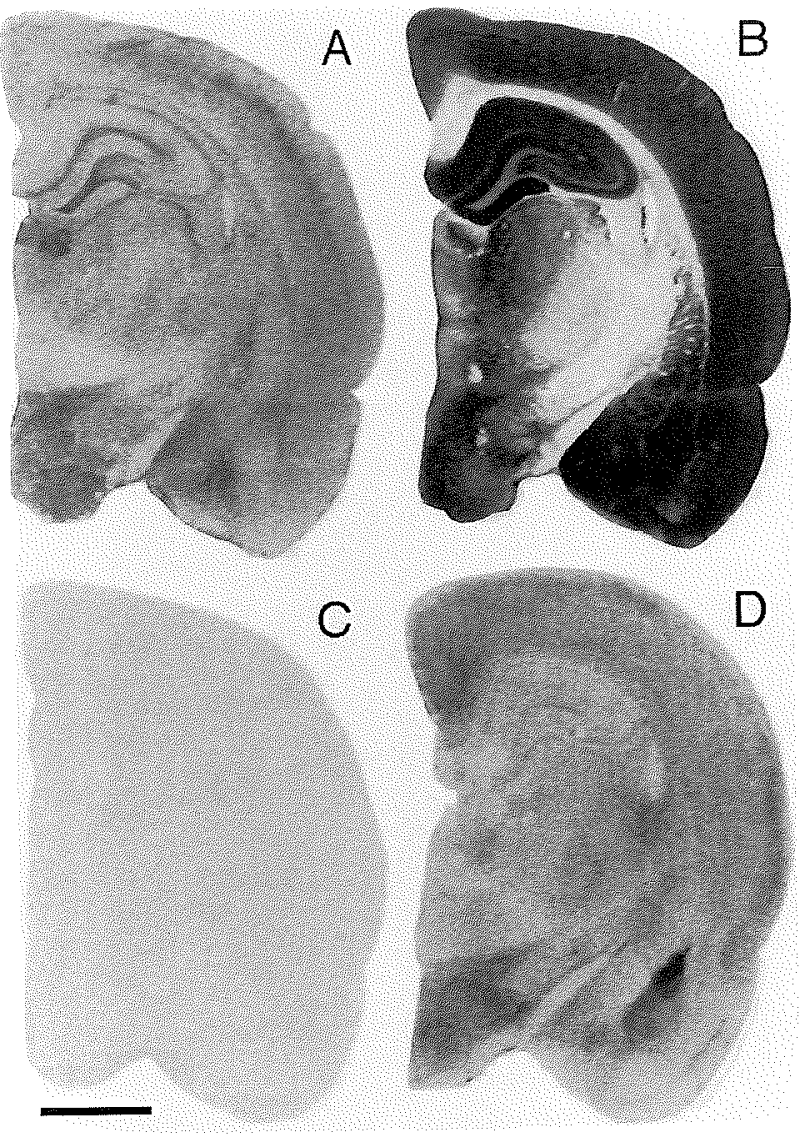

Fig. 3 Coronal sections showing macroscopic distribution of proteins. Right halves of cerebra were processed for immunocytochemical examination as described in the text. A, without perfusion and stained with anti-PAD type II; B, after perfusion for 100 min with oxygen-deprived Fluosol and stained with anti-MAP2; C, after perfusion for $100 \mathrm{~min}$ with oxygenated Fluosol and deiminated proteins were stained; D, after perfusion for 100 min with oxygendeprived Fluosol and deiminated proteins were stained. Bar, $2 \mathrm{~mm}$.

In contrast, staining was diffuse in other regions and weak in the dentate gyrus of hippocampus and the stratum radiatum moleculare. Sections treated in modification medium without diacetyl monoxime and antipyrine did not stain (data not shown).

\section{Microscopic Localization of Deiminated Proteins and PAD Type II}

For a more detailed localization of deiminated proteins after $30 \mathrm{~min}$ of perfusion with oxygendeprived Fluosol, the tissues were examined at higher microscopic magnification. Deiminated protein-positive cells were clearly visible, although no appreciable changes were noted from the profile produced by hematoxylin and eosin staining (data not shown). At that time, almost all positive cells throughout cerebrum seemed to be astrocytes. Typical deiminated protein-positive cells in the hypothalamus are represented in Figure 4A. Subsequently, with increasing perfusion time, the numbers and staining intensities of deiminated protein-positive cells appeared to increase. To our surprise, after $100 \mathrm{~min}$ of perfusion with oxygen-deprived Fluosol, the number of deiminated protein-positive cells in the amygdala was greater than that of the PAD type II-positive cells (Fig. 4B and C). Most of the former were larger in size than the enzymepositive cells and coincided with MAP2-positive neurons in the adjacent section (Fig. 4B-F). However, in such neurons, the staining intensity of deiminated proteins was relatively weaker. Neurons positive in deiminated proteins were essentially absent from other cerebral regions. In double-stained sections, smaller deiminated protein-positive cells were partially positive with GFAP, but negative with respect to oligodendroglial and microglial markers recognized by anti-MBP and the B4 isolectin of $B$. simplicifolia1 , respectively (data not shown).

Since deiminated proteins and PAD type II are not amenable to double staining, we subsequently reexamined the localization of PAD type II. PAD type II-positive cells were partially positive in concordance with GFAP positivity (Fig. 4G) in double-stained sections, although the relative extent of immunoreactivity varied. Such PAD type II-positive and GFAP-positive astrocytes were observed throughout the brain. The enzyme's immunoreactivity focused mainly in the cell bodies, whereas that of GFAP localized more in the processes. Cells positive in either the enzyme or GFAP alone were also present. The PAD type II-positive cells were distinct from neurons stained with anti-MAP2 and from other types of glial cells stained with anti-MBP and the B4 isolectin of $B$. simplicifolia-1 (data not shown).

\section{DISCUSSION}

Because PAD activity in homogenates of central nervous system tissues is relatively high (40), and this enzyme can deiminate proteins, this function has potential clinical importance. Yet, 



Fig. 4 Localization of deiminated proteins and PAD type II. Coronal sections were obtained from the cerebrum and perfused for 30 or $100 \mathrm{~min}$ as described in the text. Deiminated proteins, PAD type II, and some marker proteins were detected on the sections by indirect immunohistochemical method. A, deiminated protein-positive cells in hypothalamus perfused for $30 \mathrm{~min}$ with oxygen-deprived Fluosol. B-F, serial sections of amygdala perfused for $100 \mathrm{~min}$ with oxygen-deprived Fluosol and used for detecting PAD type II (B), deiminated proteins $(\mathrm{C}, \mathrm{E})$, and MAP2 $(\mathrm{D}, \mathrm{F})$ examined at at low magnification $(\mathrm{B}-\mathrm{D})$ and high magnification (E, F). Arrows in $E$ and $F$ indicate coinciding neuronal cells. G, double staining with anti-PAD type II (red) and anti-GFAP (blue) in amygdala perfused for $100 \mathrm{~min}$ with oxygen-deprived Fluosol. Bar, $50 \mu \mathrm{m}$. 
deimination of proteins in the central nervous system has been virtually impossible to prove ( 5 , 32). In the present study, we document a new technique in which Fluosol was used as a perfusion medium and proved indispensable for demonstrating that cerebral deimination does, indeed, occur in the milieu of physical injury and correlates with the presence of PAD type II. Inagaki and Tamura (15) found that electrophysiologically intact rat brain in situ can be kept for up to $4 \mathrm{~h}$ by perfusion with a perfluorotributyl -amine emulsion, which bears some resemblance to Fluosol. In our hands, perfusion of cerebra with fully oxygenated Fluosol for as long as 100 min caused negligible protein deimination and did not introduce measurable histological abnormality. To the contrary, perfusion with oxygendeprived Fluosol caused preferential deimination of many high-molecular-weight proteins. This differential response enabled us to regulate protein deimination in the brain in situ. The deimination of GFAP was not so conspicuous. Since GFAP was preferentially deiminated under more artificial conditions, this protein may simply be highly susceptibile to PAD type II (14). High-molecular-weight proteins are more likely target molecules in the hypoxic cerebrum in vivo. These proteins also seemed to be deiminated when the onset of perfusion was delayed after dissection of the diaphragm. Therefore, protein deimination may be a routinely occurring phenomenon that has been unnoticed due to lack of suitable detection methods. Our method for identifying deiminated proteins may provide clues that clarify the significance of protein deimination in the brain.

With respect to the characterization of PAD type II-positive cells, Vincent et al. (39) reported that some positive cells showed immunoreactivity for the astrocyte marker, GFAP. Other GFAPnegative cells in that study were classified morphologically as microglia, although they did not stain with the microglial marker. Our data agree at least in part with theirs. That is, the enzyme's immunoreactivity partially coincided with GFAP immunoreactivity under microscopic examination. Possibly, then, another population of PAD type II-positive cells also exists but does not express GFAP. Moreover, we found that the PAD type II-positive cells were distinct from not only MAP2-positive neuronal cells but also microglial cells stained with the B4 isolectin of $B$. simplicifolia-1. Thus, almost all the PAD type
II-positive cells belonged to the astrocyte population. In support of this idea was the preferential deimination of GFAP in vitro. Differential staining of PAD type II-positive cells with the astrocyte marker probably reflects the heterogeneity of astrocytes $(11,22,25,29,33)$. In this sense, PAD type II may be a useful marker for studying astrocyte heterogeneity.

The macroscopic distribution of deiminated proteins differed from that of PAD type II immunoreactivity. Generation of deiminated proteins dominated in the hypothalamus and amygdala, although most positive cells in the hypothalamus appeared to be astrocytes. This was also the case in most cerebral regions. In contrast, the number of deiminated protein-positive cells exceeded that of enzyme-positive cells in the amygdala. Close examination using adjacent sections provided convincing evidence for the appearance of deiminated proteins in PAD type II-negative but MAP2-positive neurons. This result suggests that neurons expressed the enzyme but in amounts below the level detectable by immunohistochemistry.

A loss of neuronal calcium homeostasis leading to increases in the intracellular calcium concentration has been proposed to play a major role in hypoxic and ischemic brain injury (7, 13, 24). Haun et al. (12) suggested that an influx of extracellular calcium contributes to astroglial injury during ischemia on the basis of results from experimentation with simulated ischemia in a primary culture of astrocytes. In addition, during ischemia, increases of extracellular glutamate $(6,9)$ may activate astrocytic metabotropic glutamate receptors that have been shown to release calcium from intracellular stores $(1,8,10)$. In our experiment, oxygen deficiency may have caused an elevation of the intracellular free calcium level of astrocytes by such mechanisms as influx of extracellar calcium and release from intracellular calcium stores. Not only does the activity of PADs depend on the concentration of calcium ions but also, to our knowledge, no other factors can regulate the activity of PADs in vivo as well as in vitro. Inagaki et al. (14) reported that the deimination of intermediate filament proteins requires at least a micromolar level of calcium ion in vitro. Accordingly, all the data shown here suggest that PAD type II activation occurs as follows: an oxygen deficiency causes the elevation of intracellular calcium concentrations in astrocytes expressing the enzyme, and this may, 
in turn, be followed by the enzyme's activation, which generates deiminated proteins in the cells. Whether protein deimination in the brain is beneficial to the cells or not, this process is of great interest because it occurs as an early event well ahead of measurable MAP2 degradation, a proven indicator of neuronal degeneration (17, 23). Similar situations may occur during ischemia (13) and other forms central nervous system degeneration.

Citrulline has been detected in minor subfractions of human MBP (20, 41). Additionally, citrullinated MBPs are relatively enriched in immature myelin and may be involved in the myelination process (26). Recently, our colleagues found that PAD type II localized in a stage-specific immature oligodendrocyte from rat cerebral hemisphere in vitro (4). In the present study, neither deiminated proteins nor PAD type II immunoreactivity coincided with the myelin structure. The reasonable explanation is that the cerebra of our adult rats contained so little deiminated MBP, and it was so sparsely distributed, that even our sensitive detection method did not locate it. Nevertheless, our success in identifying deiminated proteins in the cerebrum and localizing them to astrocytes and neurons indicates that this technique may be useful in identifying sites of brain damage in humans.

\section{Acknowledgments}

We thank Green Cross Co. for the supply of Fluosol. We also thank Dr T. Senshu for his critique of this work. Thanks are also due to Drs $\mathrm{K}$. Akiyama and T. Ohsawa for their helpful suggestions.

\section{REFERENCES}

1. Ahmed, Z., Lewis, C. A. and Faber, D. S. (1990) Glutamate stimulates release of $\mathrm{Ca}^{2+}$ from internal stores in astroglia. Brain Res. 516, 165-169.

2. Akiyama, K., Inoue, K. and Senshu, T. (1989) Immunocytochemical study of peptidylarginine deiminase: Localization of its immunoreactivity in prolactin cells of female rat pituitaries, Endocrinology 125, 1121-1127.

3. Akiyama, K., Inoue, K. and Senshu, T. (1990) Immunocytochemical demonstration of skeletal muscle type peptidylarginine deminase in various rat tissues. Cell Biol. Int. Rep. 14, 267-273.

4. Akiyama, K., Sakurai, Y., Asou, H. and Senshu, T. (1999) Localization of peptidylarginine deiminase type II in a stage-specific immature oligodendrocyte from rat cerebral hemisphere. Nelurosci. Lett. 274, 53-55.
5. Asaga, H. and Senshu, T. (1993) Combined biochemical and immunocytochemical analyses of postmortem protein deimination in the rat spinal cord. Cell Biol. Int. 17, 525532.

6. Benvensite, H., Drejer, J., Schousboe, A. and Diemer, N. H. (1984) Elevation of the extracellular concentrations of glutamate and aspartate in rat hippocampus during transient cerebral ischemia monitored by intracerebral $\mathrm{mi}$ crodialysis. J. Neurochem. 43, 1369-1374.

7. Choi, D. W. (1988) Calcium-mediated neurotoxicity: relationship to specific channel types and role in ischemic damage. Trends Neurosci. 11, 465-469.

8. Cornell-Bell, A. H., Finkbeiner, S. M., Cooper, M. S. and Smith, S. J. (1990) Glutamate induces calcium waves in cultured astrocytes: Long-range glial signaling, Science 247, 470-473,

9. Drejer, J., Benvensite, H., Diemer, N. H. and Schousboe, A. (1985) Cellular origin of ischemia-induced glutamate release from brain tissue in vivo and in vitro. J. Neurochem., 45: 145-151.

10. Glaum, S. R., Holzwarth, J. A. and Miller, R. J. (1990) Glutamate receptors active $\mathrm{Ca}^{2}+$ mobilization and $\mathrm{Ca}^{2+}$ influx into astrocytes. Proc. Natl. Acad. Sci. USA 87, 3454-3458.

11. Hansson, E. (1990) Regional heterogeneity among astrocytes in the central nervous system. Neurochem. Int. 16, 237-245.

12. Haun, S. E., Murphy, E. J., Bates, C. M. and Horrocks, L. A. (1992) Extracellular calcium is a mediater of astroglial injury during conbined glucose-oxygen deprivation. Brain. Res, 593, 45-50.

13. Hossmann, K. A. (1999) The hypoxic brain. Insights from ischemia research. Adv. Exp. Med. Biol. 474, 155-69.

14. Inagaki, M., Takahara, H., Nishi, Y., Sugawara, K., and Sato, C. (1989) $\mathrm{Ca}^{2+}$-dependent deimination-induced disassembly of intermediate filaments involves specific modification of the amino-terminal head domain. J. Biol. Chem. 264, 18119-18127.

15. Inagaki, M. and Tamura, M. (1993) Preparation and optical characteristics of hemoglobin-free isolated perfused rat head in situ. J. Biochem. 113, 650-657.

16. Ishigami, A., Kuramoto, M., Yamada, M., Watanabe, K., and Senshu, T., (1998) Molecular cloning of two novel types of peptidylarginine deiminase cDNAs from retinoic acid-treated culture of a newborn rat keratinocyte cell line. FEBS Lett. 433, 113-118.

17. Kitagawa, K., Matsumoto, M., Niinobe, M., Mikoshiba, K., Hata, R., Ueda, H., Handa, N., Fukunaga, R., Isaka, Y., Kimura, K., and Kamada, T. (1989) Microtubuleassociated protein 2 as a sensitive marker for cerebral ischemic damage: Immunohistochemical investigation of dendritic damage. Neuroscience 31, 401-411.

18. Kubilus, J, and Baden, H. P. (1983) Purification and properties of a brain enzyme which deiminates proteins. Biochim. Biophys. Acta 745, 285-291.

19. Laemmli, U. K. (1970) Cleavage of structural proteins during the assembly of the head of bacteriophage $\mathrm{T} 4$. Nature 227, 680-685.

20. Lamensa, J. W. E. and Moscarello, M. A. (1993) Deimination of human myelin basic protein by a peptidylarginine deiminase from bovine brain. J. Neurochem. 61, 987-996.

21. Lowry, O. H., Rosebrough, N. J., Farr, A. L., and Randall, R. J. (1951) Protein measurement with the Folin phenol reagent. J. Biol. Chem. 193, 265-275. 
22. Ludwin, S. K., Kosek, J. C., and Eng, L. F. (1976) The topographical distribution of S-100 and GFA proteins in the adult rat brain. An immunohistochemical study using horseradish peroxidase-labelled antibodies. J. Comp. Neurol. 165, 172-208.

23. Matesic, D. F. and Lin, R. C. S. (1994) Microtubleassociated protein 2 as an early indicator of ischemiainduced neurodegeneration in the gerbil forebrain. $J$. Neurochem. 63, 1012-1020.

24. Mayer, F. B. (1989) Calcium, neuronal hyperexcitability and ischemic injury. Brain Res. Rev. 14, 227-243.

25. Miller, R. H. and Raff, M. C. (1984) Fibrous and proteoplasmic astrocytes are biochemically and developmentally distinct. $J$. Neurosci. 4, 585-592.

26. Moscarello, M. A., Wood, D. D., Ackerley, C. and Boulias, C. (1994) Myelin in multiple sclerosis is developmentally immature. J. Clin. Invest. 94, 146-154.

27. Naito, R. (1978) Further studies on the use of Fluosol preparations developed since Stockholm Symposium 1977. Proc. IVth Cong. Perfluorochemical Blood Substitutes, Kyoto, pp. 33-45.

28. Ohyanagi, H., Itoh, T., Seika, M., Okamoto, M., and Mitsuno, T. (1978) Kinetic studies of oxygen and carbon dioxide transport into or from perfluorochemical particles. Proc. Ist Meeting. Intern. Soc. Artificial Organs, Tokyo, pp.90-92.

29. Raff, M. C., Abney, E. R., Cohen, J., Lindsay, R., and Noble, M. (1983) Two types of astrocytes in cultures of developing rat white matter: Differences in morphology, surface gangliosides and growth characteristics. J. Neturosci. 3, 1289-1300.

30. Rothnagel, J. A. and Rogers, G. E. (1984) Citrulline in proteins from the enzymatic deimination of arginine residues, In: Methods in Enzymology, Vol. 107, F. Wold and K. Moldave, eds. Academic Press, Orlando, pp. 624-631.

31. Senshu, T., Akiyama, K., Nagata, S., Watanabe, K., and Hikichi, K. (1989) Peptidylarginine deiminase in rat pituitary: Sex difference, estrous cycle-related changes, and estrogen dependence. Endocrinology 124, 2666-2670.

32. Senshu, T., Sato, T., Inoue, T., Akiyama, K., and Asaga, H. (1992) Detection of citrulline residues in deiminated proteins on polyvinylidene difluoride membrane. Anal.
Biochem. 203, 94-100.

33. Shehab, S. A. S., Cronly-Dillon, J. R., Nona, S. N., and Stafford, C. A. (1990) Preferential histochemical staining of proteoplasmic and fibrous astrocytes in rat CNS with GFAP antibodies using different fixatives. Brain Res. 518, 347-352.

34. Streit, W. J. (1990) An improved staining method for rat microglial cells using the lectin from Griffonia simplicifolia (GSA I-B4). J. Histochem. Cytochem. 3, 19831686.

35. Takahara, H., Okamoto, H., and Sugawara, K. (1985) Specific modification of the functional arginine residue in soybean trypsin inhibitor (Kunitz) by peptidylarginine deiminase. J. Biol. Chem. 260, 8378-8383.

36. Takahara, H., Tsuchida, M., Kusubata, M., Akutsu, K., Tagami, S., and Sugawara, K. (1989) Peptidylarginine deiminase of the mouse: Distribution, properties, and immunocytochemical localization. J. Biol. Chem. 264, 13361-13368.

37. Tarcsa, E., Marekov, L. N., Mei, G., Melino, G., Lee, S. C., and Steinart, P. M. (1996) Protein unfolding by peptidylarginine deiminase. Substrate spesificity and structural relationships of the natural substrates trichohyalin and filaggrin. J. Biol. Chem. 271, 30709-30716.

38. Terakawa, H., Takahara, H., and Sugawara, K. (1991) Three types of mouse peptidylarginine deiminase: Characterization and tissue distribution. $J$. Biochem. 110, 661666.

39. Vincent, S. R., Leung, E., and Watanabe, K. (1992) Immunohistochemical localization of peptidylarginine deiminase in the rat brain. J. Chem. Neuroanat. 5, 159168.

40. Watanabe, K., Akiyama, K., Hikichi, K., Ohtsuka, R., Okuyama, A., and Senshu, T. (1988) Combined biochemical and immunochemical comparison of peptidylarginine deiminases present in various tissues. Biochim. Biophys. Acta 966, 375-383.

41. Wood, D. D. and Moscarello, M. A. (1989) The isolation, characterization, and lipid-aggregating properties of a citrulline containing myelin basic protein. J. Biol. Chem. 264, 5121-5127. 